\title{
Naturvetenskap för yngre barn - kunskapsinnehåll i lärarstudenters beskrivningar av sin framtida undervisning
}

\author{
Anna T. Danielsson ${ }^{*, a}$, Kristina Andersson ${ }^{\mathrm{b}}$, Annica Gullberg ${ }^{\mathrm{c}}$, Anita Hussénius ${ }^{\mathrm{d}}$ \\ ansttitutionen for pedagogik, didaktik och utbildningsstudier och Centrum för genusvetenskap, \\ Uppsala universitet, och School of Education, Communication and Society, King's College London; \\ ${ }^{b}$ Institutionen för pedagogik, didaktik och utbildningsstudier och Centrum för genusvetenskap, \\ Uppsala universitet; 'Institutionen för naturvetenskap och teknik, Örebro universitet och Centrum \\ för genusvetenskap, Uppsala universitet; ${ }^{d}$ Centrum för genusvetenskap, Uppsala universitet.
}

Syftet med artikeln är att utforska vilket kunskapsinnehåll som lärarstudenter inriktade mot förskolan och grundskolans tidigare år framställer som centralt för undervisning av yngre barn i naturvetenskap. Detta utgår från antagandet att kunskap om lärarstudenters relation till naturvetenskap är en viktig del i naturvetenskapliga lärarutbildares ämnesdidaktiska kompetens. Studien använder Roberts (1982) kunskapsemfaser som ett analysverktyg för att tematisera vad lärarstudenter inriktade mot förskolan och grundskolans tidigare år framställer som centralt för naturvetenskaplig undervisning. Det empiriska materialet består av en essäuppgift där lärarstudenter $(\mathrm{N}=\mathrm{I} 44)$ reflekterar över sina egna erfarenheter och upplevelser av naturvetenskap och naturvetenskaplig undervisning samt sin framtida undervisning. De två teman som allra starkast präglar essämaterialet är den starka fokuseringen på vardagsanknytning samt att grundlägga ett naturvetenskapligt intresse hos yngre elever, medan andra aspekter av naturvetenskaplig undervisning till stor del osynliggörs. Vi menar att det att utgå från lärarstudenternas beskrivningar av naturvetenskaplig undervisning kan vara stärkande (empowering) för denna studentgrupp, då talet om förskollärares och tidigarelärares deltagande i naturvetenskapliga aktiviteter ofta fokuserar antingen brister i kunskaper eller i självförtroende.

Nyckelord: naturvetenskap, lärarutbildning, kunskapsemfaser

\section{INLEDNING}

Vid naturvetenskapliga institutioner studerar många typer av studenter, vid sidan av specialiserade naturvetare och ingenjörer även lärarstudenter, med inriktningar från förskola till gymnasium. Denna breda studentgrupp ställer naturligtvis stora krav på universitetslärarna och deras ämnesdidaktiska kompetens (pedagogical content knowledge/PCK). För biologer, fysiker och kemister som undervisar på lärarutbildningar med inriktning mot förskola och grundskolans tidigare år tillkommer dessutom svårigheten att studenternas utbildning syftar till att förbereda dem för en professionell gemenskap som avsevärt skiljer sig från den som de naturvetenskapliga

\footnotetext{
* Författarkontakt: Anna T. Danielsson, anna.danielsson@edu.uu.se

Artiklar och reflektioner är kollegialt granskade. Övriga bidragstyper granskas av redaktionen. Se www.hogreutbildning.se ISSN 2000-7558

(C)2018 Anna T. Danielsson. This is an Open Access article distributed under the terms of the Creative Commons Attribution-NonCommercial 4.0 International License (https://creativecommons.org/licenses/by-nc/4.0/), allowing third parties to share their work (copy, distribute, transmit) and to adapt it, under the condition that the authors are given credit, that the work is not used for commercial purposes, and that in the event of reuse or distribution, the terms of this license are made clear. Citation: Anna T. Danielsson (2018) «Naturvetenskap för yngre barn - kunskapsinnehåll i lärarstudenters beskrivningar av sin framtida undervisning». Högre utbildning 8, 1-13. http://dx.doi.org/10.23865/hu.v8.1112
} 


\title{
2 A. T. Danielsson et al.
}

universitetslärarna själva ingår i. Abell et al. (2009) beskriver den komplexa ämnesdidaktiska kompetens som en naturvetenskaplig lärarutbildare bör besitta som följer:

\begin{abstract}
A science teacher educator's PCK includes his/her knowledge about curriculum, instruction, and assessment for teaching science methods courses and supervising field experiences, as well as his/her knowledge about preservice teachers and orientations to teaching science teachers. For example, the science teacher educator should understand the points of resistance that prospective teachers might experience when learning about science teaching. (Abell et al., 2009, p. 79)
\end{abstract}

Kunskap om lärarstudenters relation till naturvetenskap lyfts alltså fram som en central del i den ämnesdidaktiska kompetensen. I synnerhet förskollärares och tidigarelärares relation till och kunskaper om naturvetenskap är ett område som naturvetenskapsdidaktiska forskare intresserat sig för. En naturvetenskaplig lärarutbildare som strävar efter att utöva ett akademiskt lärarskap har därför riklig forskningslitteratur att informeras och inspireras av. Emellertid är den bild av förskollärare och tidigarelärare som framkommer i denna forskningslitteratur långt ifrån oproblematisk. Ett dominerande narrativ är dessa lärares och lärarstudenters låga självförtroende och bristande ämneskunskaper i naturvetenskap. Forskning visar att det heller inte är ovanligt med negativa erfarenheter av och attityder till naturvetenskap bland lärare/lärarstudenter inriktade mot förskolan och grundskolans tidigare år (Andersson, 20II; Appelton, 2003; Appelton $\&$ Kindt, 2002). I en studie av Johnston och Ahtee (2006) uppgav en majoritet av de intervjuade lärarstudenterna inriktade mot grundskolans tidigare år att deras huvudsakliga svårighet med naturvetenskaplig undervisning var bristande ämneskunskaper. Ett liknande resultat från svenska sammanhang finns i en studie av Nilsson (2008) där blivande tidigarelärare uttrycker osäkerheter på grund av för lite ämneskunskaper. Harlen (1997) visar också att många tidigarelärare som saknar utbildning i naturvetenskap helt undviker att undervisa i ämnena, och att de som undervisar oftast väljer innehåll med anknytning till biologi. En rapport från Skolverket (2008) ger en liknande bild från Sverige, där det är vanligare att elever i årskurs fyra undervisas i biologi än i de andra naturvetenskapliga ämnena. Sammantaget präglas således en stor del av forskningen av en slags individualiserad "bristfällighetsdiskurs", där lärarutbildarens uppdrag blir att kompensera för de bristande ämneskunskaperna och hantera det låga självförtroendet och de negativa attityderna. Implicit förstås de blivande tidigarelärarna och förskollärarna ${ }^{1}$ i relation till blivande naturvetenskapliga ämnesspecialister och utan att förneka vare sig behovet av ämneskunskaper eller ämnesspecifikt självförtroende så ställer vi oss frågan hur konstruktivt ett ensidigt fokus på lärarstudenternas "brister" är. Vi menar istället att lärarstudenternas "points of resistance" (Abell et al., 2009) behöver förstås som kontextspecifika och inte begränsade till de individuella studenternas kunskaper och attityder. Sundberg och Ottander (2013) menar, till exempel, att den naturvetenskapliga kulturen kan uppfattas som stående i motsats till en omvårdande förskolekultur. På ett likande sätt visar Danielsson och Warwick (20I4) att det kan finnas konflikter mellan tidigarelärares syn på undervisning av yngre barn och deras syn på undervisning i naturvetenskap. Samtidigt som det är viktigt för lärarutbildaren att ha kunskap om sådant som kan skapa avstånd mellan naturvetenskap och förskola är det naturligtvis också centralt att förstå vad som länkar de olika gemenskaperna samman och att problematisera vad som i en

1 I fortsättningen benämns dessa båda studentgrupper som "lärarstudenter" om det inte är så att en diskussion enbart rör en av studentgrupperna. 
förskolekontext kan förstås som naturvetenskap (Andersson \& Gullberg, 20I4). Siraj-Blatchford (200I) och Siry (2013) använder begreppet "emerging science" som ett sätt att förstå en mängd vardagliga aktiviteter (vattenlek, rutschkanor, bakning) som naturvetenskapligt relevanta erfarenheter. För att kunna länka samman lärarutbildningens naturvetenskap med förskolans/de tidiga skolårens naturvetenskap blir det viktigt för den naturvetenskapliga lärarutbildaren att få kunskap om sina studenters förförståelse av (för)skolans naturvetenskap, vad som för dem framstår som centralt respektive inte centralt- för att kunna bygga vidare på och/eller utmana denna förståelse.

I en kunskapsöversikt över didaktiska frågor i relation till förskolan och grundskolans tidigare år lyfter Hartsman och Jönsson (20I0) fram att den didaktiska "hur-frågan" ofta behandlas fristående från vem-, varför- och vad-frågorna och exemplifierar med att barn ges möjligheter att observera i naturen, men att undervisningen stannar vid observationen som sådan. Elm (2008) har också visat att det naturvetenskapliga innehållet i förskolan ofta begränsas till aktiviteten i sig, utan vidare tolkningar eller förklaringar. I denna artikel studerar vi vilket innehåll som framträder tydligt respektive mindre tydligt i lärarstudenters beskrivningar av sin framtida naturvetenskapliga undervisning.

Syfte och frägeställningar

Syftet med föreliggande studie är att undersöka vad lärarstudenter inriktade mot förskolan och grundskolans tidigare år framställer som centralt för undervisning av yngre barn i naturvetenskap. Följande forskningsfråga undersöks:

- Vilka centrala teman kan identifieras i lärarstudenternas syn på naturvetenskaplig undervisning för yngre barn?

\section{KUNSKAPSEMFASER}

Kunskapsemfaser är bakomliggande syften med naturvetenskaplig undervisning och utgör ett sätt att kategorisera val av undervisningsinnehåll samt de värderingar som är kopplade till dessa val (Roberts \& Östman, 1998). Roberts (1982) har identifierat sju olika kunskapsemfaser, vilka beskriver olika sätt att förhålla sig till naturvetenskaplig kunskap: Den rätta förklaringen (Correct explanation) handlar om faktakunskaper och kommunicerar implicit att naturvetenskaplig kunskap är god kunskap som inte behöver ifrågasättas eller diskuteras. Vetenskapens intellektuella process (Structure of science) handlar om det naturvetenskapliga arbets- och tankesättet, som t.ex. vad en hypotes är eller hur vetenskapliga modeller kan konstrueras och förstås. Själv som forrklarare (Self as explainer) lyfter fram vetenskaparens roll i vetenskapandet, både i termer av hur vetenskapliga idéer är historiskt situerade och i termer av att låta elever synliggöra sin egen förståelse för vetenskapliga fenomen. Det vetenskapliga hantverket² (Scientific skill development) fokuserar på själva "hantverket", det vill säga att kunna behärska olika metoder. Den säkra grunden (Solid foundation) handlar om naturvetenskaplig kunskap såsom varande kumulativ, hur en elev behöver lära sig vissa kunskaper för att sedan kunna gå vidare med andra. Vardagsemfas (Everyday coping) fokuserar på naturvetenskapliga kunskaper såsom användbara för att förstå

2 Översätts ofta till "Den vetenskapliga metoden" (efter Östman, I995), men vi menar att "Det vetenskapliga hantverket" ligger närmare den engelska ursprungsbeteckningen. För de övriga emfaserna följer vi Östmans översättningar. 


\section{A. T. Danielsson et al.}

det vardagliga samt att socialisera elever in i en syn på naturvetenskap som vardagligt relevant och tillämpbar. Naturvetenskap, normer och beshut (Science, technology and decisions) utvidgar synen på naturvetenskapliga kunskaper till att vara tillämpliga på politiska och moraliska problem.

I denna artikel används kunskapsemfaserna som ett analysverktyg för att tematisera vad lärarstudenter inriktade mot förskolan och grundskolans tidigare år framställer som centralt för naturvetenskaplig undervisning.

\section{METOD}

Denna artikel utgår från empiri insamlad inom ramen för forsknings- och interventionsprojektet "Att utmana blivande NO-lärare". Målet med projektet var att skapa ny och fördjupad kunskap om genus och naturvetenskapligt lärande för att i förlängningen kunna bidra till en mer inkluderande naturvetenskaplig undervisning. Projektet genomfördes på lärarprogram med inriktning mot förskola och grundskolans tidigare år vid två lärosäten i Sverige. I korthet handlade interventionen om att studenternas föreställningar om genus och naturvetenskap utmanades genom att moment som behandlade frågeställningar kring naturvetenskap, undervisning och genus integrerades under utbildningens naturvetenskapliga kurser. Dessa naturvetenskapliga kurser lästes vid lärosätenas teknisk-naturvetenskapliga fakulteter och undervisades av ämnesspecialister. Interventionsmomenten designades och undervisades av artikelförfattarna, även de ämnesspecialister. Vid det ena lärosätet läser studenterna inriktade mot förskolan och grundskolans tidigare år samma naturvetenskapliga kurs, vid det andra lärosätet gavs två parallella kurser, en inriktad mot förskola och en mot grundskolans tidigare år. Studenternas deltagande i interventionsmomenten dokumenterades i form av inspelade seminarier och insamlade skriftliga uppgifter. En utförlig beskrivning av interventionen finns i Hussénius et al. (20I4). Då tidigare forskning visar att det är förhållandevis vanligt med negativa attityder till och erfarenheter av naturvetenskap bland lärare som undervisar yngre barn (Appleton, 2005; Sundberg \& Ottander, 2013) valde vi att låta studenternas reflektioner kring sina tidigare erfarenheter av naturvetenskap och naturvetenskapligt lärande utgöra en central del i projektet. Detta eftersom forskning visar att den syn en lärare har på ämnet och på sin egen relation till ämnet påverkar elevers ämnesmässiga lärande (Andersson, 20II; Beilock, Gunderson, Ramirez \& Levine, 20IO).

\section{Datainsamling och analys}

I föreliggande artikel analyseras en essäuppgift där studenterna ombeddes reflektera över sina egna erfarenheter och upplevelser av naturvetenskap och naturvetenskaplig undervisning, hur detta påverkat deras inställning till naturvetenskap samt diskutera vad de tyckte var viktigt vid undervisning av naturvetenskap för yngre barn. ${ }^{3}$ Uppgiften är skriven i en essäform och de tre föreslagna frågeställningarna behandlas på ett sammanvävt sätt i studenternas reflektioner.

3 Inlämningsuppgift I: I din kommande yrkesprofession kommer du att undervisa barn/elever i naturvetenskap. I den här uppgiften vill vi att du ska tänka tillbaka på dina egna erfarenheter och upplevelser av naturvetenskap och naturvetenskaplig undervisning, och fundera över om och på vilket sätt det påverkat din syn på/din inställning till naturvetenskap.

- Vilka erfarenheter/upplevelser har du själv av naturvetenskap? Ge gärna exempel från olika åldrar, samt från både inom och utanför skolans värld.

- Hur har dessa erfarenheter påverkat ditt förhållande till naturvetenskap?

- Vad tycker du är viktigt att tänka på när man ska undervisa barn i naturvetenskap? Utgå gärna från dina egna erfarenheter. 
Denna uppgift genomfördes av studenterna innan själva interventionen tog sin början, vid inledningen av de naturvetenskapliga kurserna. Uppgiften var obligatorisk för att få godkänt på kursen, men bedömdes inte med graderade betyg. Totalt består det analyserade materialet av I44 studentessäer, i genomsnitt en sida långa. Vid den ena lärosätet samlades material in från 55 studenter som läste en naturvetenskaplig kurs där förskollärarstudenter och studenter inriktade mot grundskolans tidigare år samläser. Vid det andra lärosätet samlades material in från 79 studenter som läste till förskollärare och Io studenter som läste till lärare för grundskolans tidigare år. Studenterna har gett sitt godkännande till användningen av essäuppgifterna i forskning och samtliga namn i artikeln är fingerade.

Analysen inleddes genom en tematisk analys (Braun \& Clark, 2006), där uttalanden om lärarstudenternas syn på sin framtida undervisning i naturvetenskap identifierades och kategoriserades. Vid upprepade genomläsningar av det empiriska materialet gjordes en detaljerad kategorisering av studenternas uttalanden, och de 23 kategorier som konstruerats användes sedan för kodning av hela det empiriska materialet. I detta analyssteg fokuserade vad studenterna ansåg bör karakterisera naturvetenskaplig undervisning av yngre barn (exempel på kategorier är: "rätt nivå", "anpassa efter barnens förkunskaper", "roligt" och "att skapa trygghet", "vardagsnära/närmiljö" och "vetenskaplig metod"). Efter detta första, empiridrivna analyssteg, syftande till att skapa en överblick över det empiriska materialet, blev det tydligt att många studentuttalanden kunde beskrivas utifrån Roberts (1982) kunskapsemfaser. I ett nästa analyssteg användes Roberts (1982) kunskapsemfaser för att ge en mer fokuserad bild av empirin. Kodningen utifrån kunskapsemfaser möjliggjorde också att identifiera vad som inte synliggörs i studenternas uttalanden. Genom att på detta sätt använda kunskapsemfaserna som ett raster för att tolka studenternas beskrivningar av hur de resonerar kring naturvetenskaplig undervisning blev det möjligt att röra sig bortom den ofta fokuserade hur-frågan (se t.ex. Hartsman \& Jönsson, 20I0 och Elm, 2008) och få syn på nyanser i vilka innehållsval och syften framstår som möjliga utifrån studenternas beskrivningar. Vidare bör sägas att såväl essäer som enskilda uttalanden kan innehålla mer än en emfas. Det finns också essäer som inte innehåller någon emfas, t.ex. därför att temat undervisning av barn i naturvetenskap är mycket kortfattat behandlat.

\section{RESULTAT}

I tabell I nedan ges en kvantitativ överblick över frekvensen av förekommande kunskapsemfaser i studentessäerna och därefter diskuteras vilka tematiker som framträder respektive står tillbaka i studenternas texter.

\section{Dominerande emfaser}

Den vanligaste förekommande kunskapsemfasen i de analyserade studentessäerna är Vardagsemfas. De studenter som är inriktade mot förskolan beskriver ofta värdet av att använda sig av förskolans närmiljö, genom att den erbjuder en möjlighet att ta vara på ögonblick och därmed koppla aktiviter och händelser till naturvetenskap:

Camilla: Vad som är viktigt att tänka på när man ska undervisa barn i naturvetenskap är att man som pedagog ska fånga ögonblicket, har det regnat på morgonen och man går ut med en barngrupp på gården och barnen börjar hoppa i vattenpussarna, kan man ställa frågor om vad det är som händer i vattnet, eller vad som händer med vattnet när solen kommer fram och värmer.

Studenter inriktade mot grundskolans tidigare år ger också exempel på hur undervisningen kan kopplas till vardagliga fenomen (t.ex. att använda bakning i kemiundervisning). Vidare 
Tabell ${ }_{\text {I. }}$ Kvantitativ översikt över $i$ hur många studentessäer varje kunskapsemfas förekommer (mer än en emfas kan förekomma i en och samma essä och det finns essäer där ingen emfas förekommer).

\begin{tabular}{lc}
\hline Kunskapsemfas & Antal essäer som behandlar emfasen (\%) \\
\hline Den rätta förklaringen & $\mathrm{I}(\mathrm{I} 2)$ \\
Den säkra grunden & $29(20)$ \\
Det vetenskapliga hantverket & $3(2)$ \\
Vetenskapens intellektuella process & $\mathrm{I7}(\mathrm{I} 2)$ \\
Själv som förklarare & $5(4)$ \\
Vardagsemfas & $53(37)$ \\
Naturvetenskap, normer och beslut & $\mathrm{I} 8(\mathrm{I} 3)$ \\
\hline
\end{tabular}

förekommer uttalanden om vikten av att på ett mer övergripande plan få eleverna att förstå relevansen av naturvetenskap utanför skolan. Denna senare tematik, som handlar om att ge eleverna insikt i hur naturvetenskaplig kunskap är betydelsefull inom en rad olika områden, kan också sägas anknyta till kunskapsemfasen Den säkra grunden. Ett relativt vanligt förekommande tema i essäerna är reflektioner kring hur inte enbart kunskaper utan också inställning till naturvetenskap grundläggs i tidiga år. Detta breda fokus på samspelet mellan intresse och kunskaper kan ses som en tolkning av hur kunskapsemfasen relaterar till att undervisa yngre barn, där förskolan ses som en viktig inkörsport till naturvetenskapligt lärande:

Nina: Jag anser att en tidig start med naturvetenskapliga ämnen påverkar barnens intresse och att börja med en tidig grund gör det kanske lättare att förstå vår miljö och saker som kan uppstå. Dörför anser jag att dessa kunskaper är viktiga och att börja med det redan i förskolan ser jag som positivt genom att barnen får då mer grepp om vårt miljöområde.

Vidare lyfter studenterna fram vikten av att barnen tidigt möter naturvetenskaplig undervisning, som en möjlighet att avdramatisera dessa ämnen:

Helen: Jag tror inte man ska vänta med alla begrepp tills högstadiet. Jag tror det kan vara nyttigt för barnen att bekanta sig med begreppsvärlden inom naturvetenskap tidigt, för att undvika den "begreppschocken" jag själv mötte i högstadiet. Jag hoppas att jag kan bidra till ett givande möte med naturvetenskap för barnen. Så att deras intressen för naturkunskap kan hållas vid liv och göra senare möten med naturkunskap spännande istället för skrämmande och "svårt".

I detta senare uttalande är det underförstått att naturvetenskap i skolans senare år ofta upplevs som svår och otillgänglig. Ett viktigt syfte med förskolans/de tidigare årens naturvetenskap blir därför att skapa bestående "motbilder" mot detta, vilket kan förstås som en del i Den säkra grunden.

Kunskapsemfasen Vetenskapens intellektuella process förekommer även den relativt frekvent i studentessäerna. Studenterna beskriver här att skapa förståelse för laborationer som vetenskaplig metod:

Paul: Jag tycker att det är viktigt att man låter eleverna få genomföra olika laborationer, för att se verkan/resultatet och inte minst behålla intresset som leder till att man vill forska vidare. Detta blir sedan som ett belägg för diskussioner, då läraren kan föra samtal med hela klassen för att reflektera över hur experimentet gick samt vilka resultat den gav. 
Det kan emellertid också handla om att få förståelse för vetenskapliga modeller, något en student exemplifierar med att fä äldre barn att förstå hur luftens kretslopp fungerar. Studenterna ger också exempel på konkreta aktiviteter/situationer (t.ex. kompostering och bakning) där man kan arbeta med att synliggöra naturvetenskapliga förklaringsmodeller, vilket anknyter till Vardagsemfasen.

En relativt vanligt förekommande tematik är även kunskapsemfasen Den rätta förklaringen, som uttrycks i 17 av essäerna och där ytterligare nio essäer dessutom diskuterar denna emfas i termer av att den ses som inte passande i en förskolekontext. I relation till positiva omnämnanden av Den rätta förklaringen kan två huvudsakliga teman urskiljas som viktiga att bibringa yngre barn. För det första diskuterar ett flertal studenter allemansrätten och vad som är tillåtet/inte tillåtet inom ramen för den, och för det andra lyfts artkunskap fram:

Christine: Jag anser att det är viktigt att barn får lära sig olika fågelarter, växtarter, småkrypsarter, djurarter och så vidare och vad de exempelvis äter, sover, lever med mera.

Det finns också studenter som på ett mer övergripande plan beskriver vikten av att lärare för yngre barn har solida ämneskunskaper, så att de kan styra barnen mot ett visst kunskapsinnehåll och/eller ge barnen svar på deras frågor:

Rebecka: Barn och elever vill verkligen experimentera, fundera, praktisera och förundras. De vill undersöka, men de vill också ha svar.

Det sista uttalandet kan förstås som att det tar spjärn emot konstruktionistiska strömningar i förskolan och motståndet mot en syn på kunskap som rätt eller fel. I nio av studentessäerna förekommer ett uttalat distanserade från kunskapsemfasen Den rätta förklaringen, där studenter vänder sig emot denna typ av kunskapssyn i en förskolekontext och menar att den t.ex. kan vara skadlig för barnens självkänsla. Flera studenter påpekar också att det viktiga är att skapa ett intresse/nyfikenhet, något som ställs i motsats till kunskap som sådan:

Jennie: Det är inte kunskapen i sig som är viktigast utan att deras intresse för naturen ska väckas. Genom små lätta experiment skapas en förundran och en förståelse, det är oftast lättare att förstå något genom att utföra det praktiskt.

Kunskapsemfaserna Vardagsemfas, Den rätta förklaringen och Den säkra grunden sammansmälter när studenterna talar om naturvetenskapens tillämplighet för moraliska och politiska problem som motsvaras av emfasen Naturvetenskap, normer och beslut. Sådana diskussioner om moraliska och politiska tillämpningar handlar uteslutande om att lära barnen att värna om naturen/miljön, både i det direkta och vardagliga (t.ex. att källsortera eller att inte slänga skräp i naturen) och i det mer övergripande:

Malin: De allvarliga klimatförändringar och miljöhot som vår värld står inför gör att naturvetenskap har blivit ett allt viktigare ämne. Våra barn måste från tidig ålder lära sig att se och förstå att allt $\mathrm{i}$ vår natur hänger ihop och är beroende av varandra och att om vi rubbar på systemen påverkar det inte bara oss utan kommande generationer.

Ofta präglas studenternas texter av tankar om hur viktigt det är att förskolan grundlägger ett livslångt miljömedvetande (vilket även anknyter till kunskapsemfasen Den säkra grunden), hur 


\section{A. T. Danielsson et al.}

naturupplevelser och vardagsageranden kan hjälpa barnen att få en insikt i att de är del i och kan påverka miljön på en global skala:

Ann-Sofie: En annan sak som är viktig att tänka på, är att få dem att förstå vikten av att värna om vår miljö. Det är viktigt att sträva efter att lära dem vad man får och inte får göra i naturen (Allemansrätten). Jag har inte själv tänkt på att varje liten sak vi förbättrar, hjälper miljön, förrän i vuxen ålder och detta vill jag motverka genom att på ett tidigt stadium, få barnen att känna sin delaktighet i naturens kretslopp. [...] Det är i förskolan vi måste lägga grunden till deras medvetna miljötänkande. Källsortering och kompostering är en viktig del av förskolans verksamhet, liksom egna odlingar av grönsaker, där man använder sig av den jord som blir i komposten efter matrester och liknande.

Emellertid är det slående att samtliga studentuttalanden som kan ses som representerande kunskapsemfasen Naturvetenskap, normer och beslut är normerande; det handlar om att lära barn agera på vissa korrekta sätt i relation till naturen och omgivningen. Denna kunskapsemfas begränsas därmed till att handla om Den rätta förklaringen, att kunna agera miljömedvetet på ett sätt som inte behöver problematiseras.

Sammantaget präglas essäerna som helhet av ett fokus på vardagsanknytning samt vikten av att tidigt väcka ett intresse för naturvetenskap, här tolkat i termer av Den säkra grunden.

\section{Mindre framträdande emfaser}

I ett fåtal essäer förekommer uttalanden som handlar om att barnen ska få syn på sin egen och andras förståelse för olika fenomen (Själv som förklarare):

Miriam: Man upplever bra känsla när man gör ett experiment med sina egna händer och man blir öppen att testa fram flera andra tester. Alla de testerna ska eleverna kunna göra i grupp så att de kan diskutera med andra och kunna skriva sina hypoteser och resultat. Att utrusta eleverna med olika verktyg och att ge ett utrymme för elever att de ska prova och testa andra saker för att få fram en egen uppfattning om experimentet.

En student beskriver också vikten av att få insikt i hur naturvetenskapliga kunskaper växt fram historiskt. I essämaterialet som helhet är emellertid uttalanden som explicit handlar om att låta barnen få syn på sin egen (och andras) förståelse för fenomen sällsynta. Den bredare tematiken kring vikten av att vara lyhörd inför barns kunskaper, intressen och erfarenheter kan dock ses som närliggande kunskapsemfasen Själv som förklarare, även om fokus här är mer på pedagogens insikt i barnens tänkande.

Beskrivningar av naturvetenskapliga aktiviteter syftande till att lära barn olika aspekter av det vetenskapliga hantverket är till stor del frånvarande i de analyserade essäerna, men det förekommer några exempel på texter där det är det praktiska tillvägagångssättet i sig som lyfts fram:

Alva: Vad jag tycker är viktigt att tänka på när man ska undervisa barn i naturvetenskap är att göra det just spännande och praktiskt. Att man kan dissekera i väldigt tidig ålder när det handlar om små och inte så avancerade djur som ex fisk.

Sammantaget är alltså kunskapsemfaserna Det vetenskapliga hantverket samt Själv som förklarare relativt osynliggjorda i studentessäerna. Vidare är innehåll associerat till kunskapsemfasen Naturvetenskap, normer och beslut begränsat till att lära sig fatta korrekta beslut ur miljösynpunkt. 
Sammanfattning av analysen

I det empiriska materialet som helhet är kunskapsemfasen Vardagsemfas den mest framträdande. I synnerhet de studenter som är inriktade mot förskolan beskriver ofta vikten av att använda närmiljön och att uppmärksamma naturvetenskapliga aspekter i vardagliga aktiviteter. Den säkra grunden och Vetenskapens intellektuella process är också framträdande i materialet. Den säkra grunden tolkas som att dels grundlägga ett naturvetenskapligt intresse tidigt, dels att delge eleverna vissa grundläggande begrepp för att underlätta för fortsatta naturvetenskapliga studier. Beskrivningar som syftar till förståelse av den naturvetenskapliga praktiken (Det vetenskapliga hantverket) samt att låta barnen få syn på egen/andras förståelse för naturvetenskapliga fenomen (Själv som förklarare) är ovanliga. Kunskapsemfasen Den rätta förklaringen kan sägas dela studentgruppen. I synnerhet bland studenter inriktade mot förskolan finns starka åsikter, både om vikten av att ge barn svar/korrekta förklaringar och ett motstånd mot en alltför kunskapscentrerad syn på naturvetenskapliga aktiviteter (som då ställs i motsats mot t.ex. emotionella och estetiska aspekter, vilka lyfts fram som centrala för förskolans verksamhet). Vad gäller kunskapsemfasen Naturvetenskap, normer och beslut är det påfallande hur majoriteten av uttalanden som kategoriserats som tillhörande/möjliggörande denna emfas också kategoriserats som Den rätta förklaringen. Detta normativa anslag gör att det går att ifrågasätta kategorisering av dessa uttalande som Naturvetenskap, normer och beslut, men som vi diskuterar nedan menar vi att även dessa normativa uttalanden kan möjliggöra denna kunskapsemfas.

\section{DISKUSSION OCH IMPLIKATIONER FÖR LÄRARUTBILDARE}

I artikeln har vi använt oss av Roberts (1982) kunskapsemfaser som ett verktyg för att få syn på vilket kunskapsinnehåll som lärarstudenter inriktade mot förskolan och grundskolans tidigare år framställer som centralt. Hur många kunskapsemfaser som inkluderas är inte ett mått på kvaliteten hos naturvetenskaplig undervisning, men de utgör ändå en god utgångspunkt för att uppmärksamma vad som synliggörs respektive osynliggörs i lärarstudenters beskrivningar av naturvetenskaplig undervisning. Att på detta sätt utgå från lärarstudenternas beskrivningar kan också vara stärkande (empowering) i sig menar Andersson (2OII), då talet om förskollärares och tidigarelärares deltagande i naturvetenskapliga aktiviteter ofta präglas av en bristfällighetsdiskurs, med fokus på antingen brister i kunskaper eller i självförtroende (Hussénius, Andersson, Gullberg \& Scantlebury, 20I3). Studenterna i studien hade vid tidpunkten för essäskrivandet inte inlett sina universitetsstudier i naturvetenskap och essäerna utgår därför till stor del från deras egna skolerfarenheter av naturvetenskaplig undervisning (kompletterade med andra naturvetenskapliga erfarenheter och i vissa fall de egna barnens skolerfarenheter). Detta till trots förekommer visioner om naturvetenskaplig undervisning som kan hänföras till samtliga kunskapsemfaser, även om vissa emfaser är mer framträdande än andra i essämaterialet. Studentgruppens syn på naturvetenskaplig undervisning kan alltså fungera som en god utgångspunkt för att inom lärarutbildningen lyfta fram en mångfacetterad naturvetenskaplig undervisning.

De två teman som allra starkast präglar essämaterialet som helhet är fokuseringen på vardagsanknytning samt att grundlägga ett naturvetenskapligt intresse hos yngre barn. Vardagsanknytningen av förskolans naturvetenskap är inget som explicit uttrycks i läroplanen, men kopplar tydligt till de mer allmänna skrivningarna i förskolans läroplan om att "verksamheten ska utgå från barnens erfarenhetsvärld, intressen, motivation och drivkraft att söka kunskaper" (Skolverket, 20I6, s.6). I grundskolans kursplaner för biologi, kemi och fysik är vardagsanknytningen av naturvetenskapen mer preciserad, där står i samtliga kursplaner att 
eleverna ska ges möjlighet att ställa frågor om naturvetenskapliga "företeelser och sammanhang utifrån egna upplevelser och aktuella händelser" (kursplanerna i fysik, kemi och biologi, Skolverket, 20II) och i det centrala innehållet för årskurs I-3 är tydligt anknutet till barns vardagsnära livsvärld (t.ex. "tyngdkraft och friktion som kan observeras vid lek och rörelse, till exempel i gungor och rutschbanor" (kursplanen i fysik, Skolverket, 20II)). Lärarstudenternas ambition att vardagsanknyta sin framtida undervisning har således tydligt stöd i läroplanerna, och man kan förvänta sig att detta också uppmärksammas under lärarutbildningens naturvetenskapliga kurser. När så sker menar vi emellertid att det är viktigt att inte bortse från den didaktiska frågan "för vem" - vems vardag är det som undervisningen anknyts till? Denna aspekt blir särskilt relevant i relation till de starkt könskodade områdena inom naturvetenskap, där det är viktigt att som lärare vara uppmärksam på könsstereotypiserande antaganden om barns intressen. Till exempel visar studier att det inte är ovanligt att aktiviteter tolkas utifrån könet på det barn som är involverat i den naturvetenskapliga aktiviteten (Gullberg et al., in press; Kahle \& Meece, 1994). Att så starkt fokusera på att väcka intresse/nyfikenhet har tidigare problematiserats i forskningen. Bland annat menar Eshach (2006) att små barn redan är nyfikna på att utforska sin omgivning och att detta därför inte är någonting som uttryckligen behöver tas hänsyn till i undervisningen. deWitt et al. (20I4) visar också i en omfattade kvantitativ studie av yngre barns intresse för naturvetenskap och aspirationer till naturvetenskapliga yrken att en stor majoritet av barnen uttrycker positiva attityder till naturvetenskap, men fà aspirerar till naturvetenskapliga yrken. Andersson och Gullberg (20I4) menar att fokus istället bör läggas på naturvetenskapens möjligheter till empowerment, dvs. att barns självförtroende kan stärkas om de tidigt själva får vara med om att hitta lösningar på frågor och problem. Naturvetenskap kan på så sätt bli ett kraftfullt verktyg för den egna personliga utvecklingen.

Med tanke på styrkan hos synen på naturvetenskap som en kunskapsmassa ("science as a body of knowledge", se till exempel Bryan, 2003; Carlone, 2004 och Carlone, Haun-Frank \& Kimmel, 20IO) är tendensen hos studenterna att även behandla värdefrågor inom naturvetenskapen som kunskapsfrågor knappast förvånande. De studentuttalanden som kategoriserats som kunskapsemfasen Naturvetenskap, normer och beshut intar, som tidigare framhållits, till övervägande del en normerande utgångspunkt. Det handlar om att på ett oproblematiserat sätt lära barnen handla på korrekta sätt (t.ex. att källsortera) utifrån fördefinierade värderingar. Hedefalk (20I4) menar att undervisning som utgår från fördefinierade värderingar som barn ska lära sig blir begränsande för barns kritiska handlingsförmåga. När en viss handling framställs som den korrekta, fråntas barn möjlighet att värdera olika alternativ och själva ta ställning (Hedefalk, 20I4). Hon menar istället att barn i olika sammanhang, genom undervisning, ska tränas i att ställa kritiska frågor och göra värderingar. Här blir det således viktigt för lärarutbildaren att utvidga och nyansera naturvetenskapens tillämpning på moraliska och politiska problem (och också bredda dessa bortom att uteslutande handla om hållbar utveckling), i linje med skrivningar i förskolans läroplan att barn ska utveckla "sin förmåga att upptäcka, reflektera över och ta ställning till olika etiska dilemman och livsfrågor i vardagen" (Skolverket, 20I6, s. 8). Även läroplanen för grundskolan poängterar att elever ska kunna formulera självständiga ståndpunkter grundade på etiska överväganden. Det bör emellertid påpekas att en dylik nyansering av naturvetenskapens tillämpning på moraliska och politiska problem inte står i motsats till att också undervisa om vissa aspekter, som hållbarhet, utifrån Den rätta förklaringen (i förskolans läroplan står t.ex. att "förskolan ska medverka till att barnen tillägnar sig ett varsamt förhållningssätt till natur och miljö" (Skolverket, 20I6, s. 7) och i grundskolans läroplan uttrycks att målet är att varje elev " visar respekt för och omsorg om såväl närmiljön som miljön i ett vidare perspektiv" (Skolverket, 20II, s. 7)). 
I denna artikel argumenterar vi för att kunskap om hur lärarstudenter inriktade mot förskolan och grundskolans tidigare år ser på naturvetenskap och naturvetenskaplig undervisning är en central ämnesdidaktisk kunskap för lärarutbildare som undervisar i naturvetenskap. Vi hoppas också att tillvägagångssättet $\mathrm{i}$ artikeln kan inspirera lärarutbildare som själva vill undersöka sina lärarstudenters förförståelse av naturvetenskaplig undervisning. Vi har valt att utgå från studentperspektivet, alltså vad lärarstudenterna själva ser som önskvärt i sin framtida undervisning. Emellertid är forskning som tar utgångspunkt i lärarutbildarperspektivet mycket knapphändig (Berry \& van Driel, 20I3) och ytterligare forskning som undersöker lärarutbildares undervisning i naturvetenskap och naturvetenskapernas didaktik viktigt för utvecklingen av lärarutbildningarnas naturvetenskapliga undervisning.

\section{FÖRFATTARPRESENTATIONER}

Anna Danielsson är universitetslektor och docent i didaktik vid Institutionen för pedagogik, didaktik och utbildningsstudier och gästforskare vid Centrum för genusvetenskap, Uppsala universitet. Hennes forskning är fokuserad på naturvetenskapernas didaktik, med fokus på frågor om genus, identitet och makt.

Kristina Andersson är lektor i didaktik vid Uppsala universitet. Hennes forskningsintresse är genus- och feministiska perspektiv på naturvetenskaplig undervisning främst inriktat mot högre utbildning. Hon undervisar på de olika lärarprogrammen men också i genusvetenskap på Centrum för genusvetenskap, Uppsala universitet.

Annica Gullberg har doktorsexamen i genetik. Under de senaste 20 åren har hennes forskningsintresse varit inom de naturvetenskapliga ämnenas didaktik speciellt med fokus på ett genusperspektiv. Annica är lektor vid Örebro universitet och gästforskare vid Centrum för genusvetenskap vid Uppsala universitet.

Anita Hussénius är föreståndare och forskare vid Centrum för genusvetenskap, Uppsala universitet, samt universitetslektor i kemi vid Högskolan i Gävle. Hennes forskning fokuserar på naturvetenskaplig praktik och undervisning i akademiska miljöer, med genus/feministiska perspektiv.

\section{REFERENSER}

Abell, S.K., Park Rogers, M.A., Hanuscin, D.L., Lee, M.H., \& Gagnon, M.J. (2009). Preparing the Next Generation of Science Teacher Educators: A Model for Developing PCK for Teaching Science Teachers. Journal of Science Teacher Education, 20(I), 77-93. doi:I0.I007/sI0972-008-9115-6

Andersson, K. (20II). Lärare för förändring: att synliggöra och utmana föreställningar om naturvetenskap och genus. Norrköping: Linköpings universitet.

Andersson, K., \& Gullberg, A. (2OI4). What is science in preschool and what do teachers have to know to empower children? Cultural Studies of Science Education, 9(2), 275-296. doi: I0.I007/sII422-0I2-9439-6

Appelton, K. (2003). How do beginning primary school teachers cope with science? Research in Science Education, 33, I-25.

Appleton, K. (2005). Science pedagogical content knowledge and elementary school teachers. In K. Appleton (Ed.), Elementary science teacher education: International perspectives on contemporary issues and practice. Mahwah, N.J.: L. Erlbaum Associates.

Appelton, K., \& Kindt, I. (2002). Begining elementary teachers' development as teachers of science. Journal of Science Teacher Education, I3(I), 43-6I. doi: http://dx.doi.org/IO.I023/A:I0I518180996I

Beilock, S. L., Gunderson, E. A., Ramirez, G., \& Levine, S. C. (2010). Female teachers' math anxiety affects girls' math achievement. Proceedings of the National Academy of Sciences, I07(5), 1860-1863. doi: http://dx.doi.org/I0.1073/pnas.0910967107

Berry, A., \& van Driel, J. (20I3). Teaching about teaching science: Aim, strategies, and backgrounds of science teacher educators. Journal of Teacher Education, 64(2), II7-I28. 
Braun, V., \& Clark, V. (2006). Using thematic analysis in psychology. Qualitative Research in Psychology, 3(2), 77-IOI.

Bryan, L. A. (2003). Nestedness of beliefs: examining a prospective elementary teacher's belief system about science teaching and learning. Journal of science teaching 40(9): 835-868.

Carlone, H. B. (2004). The cultural production of science in reform-based physics: girls' access, participation, and resistance. Journal of Research in Science Teaching 4I(4): 392-4I4.

Carlone, H. B., Haun-Frank, J., \& Kimmel, S.C. (20I0). Tempered radicals: elementary teachers' narratives of teaching science within and against prevailing meanings of schooling. Cultural Studies of Science Education 5(4): 94I-965.

Danielsson, A. T., \& Warwick, P. (2014). 'You Have to Give Them Some Science Facts': Primary Student Teachers' Early Negotiations of Teacher Identities in the Intersections of Discourses About Science Teaching and About Primary Teaching. Research in Science Education, 44(2), 289-305. doi: I0.1007/ SIII65-OI3-9383-9

deWitt, J., Archer, L., \& Osborne, J. (20I4). Science-related Aspirations Across the Primary-Secondary Divide: Evidence from two surveys in England. International Journal of Science Education, 36(10), I609-I629. Doi: 10.1080/09500693.2013.871659.

Elm, A. (2008). Interaktion och naturvetenskap i förskola och förskoleklass. Stockholm: Stockholms universitet.

Eshach, H. (2006). Science literacy in primary schools and pre-schools. Dordrecht: Springer.

Gullberg, A., Andersson, K., Danielsson, A.T., Scantlebury, K., \& Hussénius, A. (in press). I Pre-service teachers' views of the child - Reproducing or challenging gender stereotypes in science in preschool. Accepted for publication in Research in Science Education.

Harlen, W. (1997). Primary Teachers' Understanding in Science and its Impact in the Classroom. Research in Science Education, 27(3), 323-337.

Hartsman, N., \& Jönsson, K. (20IO). Lärandets vem, varför, vad och hur i förskolan och grundskolans tidiga år. In I. Tallberg Broman \& S. Persson (red.), Perspektiv på barndom och barns lärande. En kunskapsöversikt om lärande i förskolan och grundskolans tidigare år (pp. I2I-174). Stockholm: Skolverket.

Hedefalk, M. (20I4). Förskola för hållbar utveckling Förutsättningar för barns utveckling av handlingskompetens för hållbar utveckling. Uppsala: Acta Universitatis Upsaliensis.

Hussénius, A., Andersson, K., Gullberg, A., \& Scantlebury, K. (2013). Ignoring half the sky: A feminist perspective on the missing standpoints in science education research. In N. Mansour \& R. Wegerif (Eds.), Science Education for Diversity in Knowledge Society. Rotterdam: Springer Publisher.

Hussénius, A., Andersson, K., Danielsson, A., \& Gullberg, A. (20I4). Ämnesinnehåll och genusmedvetenhet i samspel för en mer inkluderande naturvetenskap. Högre utbildning, 4(2), I09-I25.

Johnston, J., \& Ahtee, M. (2006). Comparing primary student teachers' attitudes, subject knowledge and pedagogical content knowledge needs in a physics activity. Teaching and Teacher Education, 22, 503-512.

Kahle, J. B., \& Meece, J. L. (1994). Research on gender issues in the classroom. In D. Gable (Ed.), Handbook of Research in Science Teaching. New York: MacMillian Publishing Company.

Nilsson, P. (2008). Learning to teach and teaching to learn: Primary science student teachers' complex journey from learners to teachers. Norrköping: Linköpings universitet.

Roberts, D. A. (1982). Developing the concept of "curriculum emphases" in science education. Science Education, 66(2), 243-260.

Roberts, D. A., \& Östman, L. (1998). Problems of meaning in science curriculum. London: Teachers College Press.

Siraj-Blatchford, J. (200I). Emergent science and technology in the early years. Paper presented at the XXIII World Congress of OMEP. Santiago Chile July 31 to 4 August 200I.

Siry, C. (2013). Exploring the complexities of children's inquiries in science: Knowledge production through participatory practices. Research in Science Education, 43(6), 2407-2430. DOI I0.1007/ siII65-0I3-9364-z.

Skolverket (2008). Vad händer i NO-undervisningen? ISBN: 978-9I-85545-52-0 
Skolverket (2OII). LgrII - Läroplan för grundskolan, förskoleklassen och fritidshemmet 20II. Stockholm: Skolverket. Hämtad september 2017 från: https://www.skolverket.se/laroplaner-amnen-och-kurser/ grundskoleutbildning/grundskola/laroplan

Skolverket (2016). Lpfö98, Läroplan för förskolan, reviderad 2016. Stockholm: Skolverket. Hämtad september 2017 från: https:/www.skolverket.se/laroplaner-amnen-och-kurser/forskola

Sundberg, B., \& Ottander, C. (2013). The Conflict Within the Role: A Longitudinal Study of Preschool Student Teachers' Developing Competence In and Attitudes Towards Science Teaching in Relation to Developing a Professional Role. Journal of Early Childhood Teacher Education, 34(I), 80-94. doi: http://dx.doi.org/I0.I080/I0901027.2013.758540

Östman, L. (1995). Socialisation och mening: No-utbildning som politiskt och miljömoraliskt problem Uppsala Studies in Education, 6r. Stockholm. 